\title{
Physiological suitability of six West African gramineous borers (Lepidoptera: Noctuidae, Pyralidae) for development of Cotesia species complex (Hymenoptera: Braconidae)
}

\author{
Y. Hailemichael ${ }^{1,2 *}$, F. Schulthess ${ }^{2,3}$, J.W. Smith $\mathrm{Jr}^{1}$ \\ and W.A. Overholt ${ }^{4}$ \\ ${ }^{1}$ Biological Control Laboratory, Department of Entomology, Texas A\&M \\ University, College Station, Texas 77843-2475, USA: ${ }^{2}$ Biological Control \\ Center of Africa, International Institute of Tropical Agriculture, \\ 08BP 0932 Tripostal, Cotonou, Benin: ${ }^{3}$ Postfach 508-4, Chur, Switzerland: \\ ${ }^{4}$ Department of Entomology and Nematology, University of Florida, \\ Fort Pierce, Florida 34945, USA
}

(Accepted 17 August 2009)

\begin{abstract}
Three gregarious, endoparasitic braconids, a Kenyan strain of Cotesia sesamiae, and the exotic Cotesia flavipes and Cotesia chilonis were imported into Benin as candidates for biological control of stem- and cob borers of maize and stemborers of millet. Host acceptability and host suitability of six gramineous borers occurring in western Africa, the noctuids Sesamia calamistis, Sesamia poephaga, Busseola fusca, the crambid Coniesta ignefusalis, and the pyralids Eldana saccharina and Mussidia nigrivenella, to these parasitoids were evaluated to test the hypothesis that new associations were superior over old association parasitoid-host relationships. All hosts were accepted by all Cotesia spp., except M. nigrivenella, which was not attacked by C. chilonis. Parasitoid progeny developed successfully in S. calamistis, S. poephaga and C. ignefusalis. S. calamistis was the most suitable host in terms of duration of developmental time, brood size and mortality of parasitoid progeny. It was concluded that because of its host specificity, the old association parasitoid C. sesamiae would have the highest chance of establishment in cereal systems in West Africa.
\end{abstract}

Key words: Cotesia, stemborer, host acceptability, host suitability, encapsulation, biological control, new associations, maize, West Africa

\section{Introduction}

Economically important lepidopteran pests attacking cereal crops in West Africa include the stemboring noctuids Sesamia calamistis Hampson, Sesamia poephaga Tams and Bowden, Busseola fusca

*E-mail: yhailemichael@sbcglobal.net
(Fuller), and the pyralids Eldana saccharina (Walker), Coniesta ignefusalis (Hampson) and the cob borer Mussidia nigrivenella Ragonot. With the exception of C. ignefusalis, which is a pest of pearl millet in the Sudano-Sahelian zone, and M. nigrivenella, which is a pest of maize cobs from the humid forest to the Northern Guinea Savanna, these borers cause economic damage to cultivated gramineous crops 
in the forest and forest-savanna transition zones only (Schulthess et al., 1997; Sétamou et al., 2000). Economic damage to cultivated gramineous crops in West Africa is restricted to the forest and forestsavanna transition zones, and the mid-altitude region (Schulthess et al., 1997). Extensive surveys conducted in several western African countries showed that larval parasitization of stemborers was generally low and considered insufficient for stemborer suppression in agricultural crops (Gounou et al., 1994; Bosque-Pérez et al., 1995; Conlong, 2001; Ndemah et al., 2001, 2007).

Biological control against lepidopterous stemborers native to Africa has been proposed since the 1970s (Greathead, 1971; Mohyuddin et al., 1981; Mohyuddin, 1991). Schulthess et al. (1997) suggested expanding the range of indigenous natural enemies within Africa. Increased interest and research on the stemborers and their natural enemies across Africa have revealed that the complex of stemborers and their associated parasitoids, as well as their relative economic importance, differs throughout the continent. For example, S. calamistis is broadly distributed throughout sub-Saharan Africa, whereas most other Sesamia species have a more limited distribution and are only of local economic importance (Harris, 1962). Several reports have suggested the existence of biological strains of certain species of both stemborers and their natural enemies. For example, the braconid parasitoid Cotesia sesamiae Cameron successfully parasitized and developed in B. fusca in South Africa (Ullyett, 1935; Kfir and Bell, 1993; Kfir, 1995, 1998) and in East Africa, from where two biotypes are reported (Ngi-Song et al., 1998; Mochiah et al., 2001; Zhou et al., 2003). A C. sesamiae biotype from inland Kenya successfully developed on B. fusca while the coastal strain was completely encapsulated by B. fusca (Ngi-Song et al., 1998; Zhou et al., 2003). A number of surveys have shown that C. sesamiae is rare in western Africa (Bosque-Pérez et al., 1995; Conlong, 2001; Ndemah et al., 2001, 2007), whereas in East and southern Africa, it is a common parasitoid of $S$. calamistis and B. fusca (Ingram, 1958; Kfir and Bell, 1993; Kfir, 1995, 1998).

The following study was part of a broader programme that addressed biological control of gramineous stemborers in sub-Saharan Africa. Thereby, the feasibility of using three species of palaeotropical Cotesia, namely the native C. sesamiae and the exotic C. flavipes Cameron and Cotesia chilonis (Matsumura), for control of West African stemborers was evaluated. Thus C. sesamiae reared on S. calamistis, and C. flavipes and C. chilonis reared on the crambid Chilo partellus (Swinhoe) at the International Centre of Insect Physiology and Ecology (icipe), Nairobi, Kenya, were introduced into the containment facilities of the International
Institute of Tropical Agriculture (IITA), Benin. C. sesamiae is aboriginal to many regions of Africa where it attacks a wide range of stemborer hosts and shares a common evolutionary history with several African gramineous borers (Ullyett, 1935; Ingram, 1958; Mohyuddin, 1971; Walker, 1994). Cotesia flavipes and C. chilonis are Asian in origin (Polaszek and Walker, 1991) and thus share no common evolutionary relationship with native African stemborers.

Before releasing these parasitoids, host suitability and host acceptability of cob and stemborers inhabiting wild and crop plants in West Africa were investigated. For laboratory rearing, hosts were selected, which had an opportunity to co-adapt with the parasitoid (Smith et al., 1993, Wiedenmann and Smith, 1997). In the present study, S. calamistis was considered a natural host for $C$. sesamiae and a new association host for $C$. flavipes and C. chilonis. New association hosts may be acceptable hosts for oviposition and may be completely, or partially suitable, or unsuitable for parasitoid development. Given the opportunity that West African gramineous stemborers have had an opportunity to co-adapt with $C$. sesamiae, we ask can host acceptability and host suitability differences be useful to quantify a physiological adaptation of these parasitoids to potential hosts in West Africa?

The objectives of the current experiment were to determine first whether $C$. sesamiae, $C$. chilonis and C. flavipes would attack and oviposit, and whether the subsequent progeny would complete development in the stemborers E. saccharina, S. calamistis, S. poephaga, C. ignefusalis, B. fusca and the cob borer $M$. nigrivenella. The data generated from these behavioural and physiological experiments would provide insight into the suitability of the different borers for Cotesia species development.

\section{Materials and methods}

\section{Parasitoid and host culture}

The C. chilonis laboratory culture originated from field collected Chilo suppressalis (Walker) on rice, Oryza sativa L., in Niigata, Japan via The Biological Control Facility, Texas A\&M University, College Station (Oketch and Overholt, 1996). C. flavipes originated from C. partellus at Rawalpindi, Pakistan, from maize (Overholt et al., 1994). C. sesamiae was reared from field collected $S$. calamistis from maize from the coastal zone of Kenya (Ngi-Song et al., 1995). Laboratory cultures of C. flavipes and C. chilonis were maintained on C. partellus, and C. sesamiae on S. calamistis for several generations at icipe, Nairobi, Kenya, prior to shipment to Cotonou, Benin. Individuals from the Kenyan cultures were imported into the IITA-Benin laboratory in 1994, 
and all three parasitoids were subsequently cultured using locally collected $S$. calamistis as the host. All laboratory experiments and stemborer and parasitoid cultures, unless otherwise specified, were maintained at $26 \pm 2{ }^{\circ} \mathrm{C}$, a photoperiod of $12 \mathrm{~h}$ light- $12 \mathrm{~h}$ dark and humidity of $50-90 \%$. Adult parasitoids were fed with $20 \%$ honey-water solution before exposure of host larvae.

All hosts were reared on artificial diets developed by Bosque-Pérez and Dabrowski (1989), and Bolaji and Bosque-Pérez (1998).

\section{Host exposure microhabitat}

Larval feeding tunnels $4 \mathrm{~cm}$ long were constructed in $8 \mathrm{~cm}$ long maize or millet stems, or maize cobs by boring a $2 \mathrm{~mm}$ diameter tunnel longitudinally in the centre of each stem with a cork borer. This facilitated larval entry into the stem, and subsequent larval feeding and tunnelling. Using soft forceps, one fourth instar larva was introduced head first into each tunnel. The larva was left to feed and produce frass for at least $30 \mathrm{~min}$. The arena for host exposure was a $165 \mathrm{ml}$ clear plastic container tightly covered with a plastic top. Each top had a central hole of $2.5 \mathrm{~cm}$ diameter plugged with cotton wool. One infested stem or cob was placed in each arena.

\section{Host acceptability}

Fourth instar larvae were offered with their associated host plant material for parasitism to the parasitoid. Female parasitoids $(6-8 \mathrm{~h}$ old $)$ were gently transferred into each plastic container using a 1:1 parasitoid-to-host ratio. A cohort of 25 larvae for each host-parasitoid pairing was prepared; five larvae were left unexposed and the remaining 20 larvae were exposed to parasitoids. For each host-parasitoid pairing, six cohorts were used. After a $24 \mathrm{~h}$ exposure period, the larvae were removed from the plant material and 10 parasitized larvae were dissected to estimate the percentage of hosts accepted. The remaining ten larvae were placed on artificial diet and observed for parasitoid emergence.

Ten host larvae were longitudinally dissected in a $56.7 \mathrm{~cm}^{2}$ Petri dish using pointed forceps. Water was flushed into the internal tissue and the Petri dish was gently shaken to distribute the contents evenly. Eggs were counted under a $\times 40$ magnification. Several $0.053 \mathrm{~cm}^{2}$ squares of a grid were thoroughly examined to determine the presence or absence of parasitoid eggs. Once the presence of parasitoid eggs was confirmed, ten fields of vision (which constituted $0.93 \%$ of the total area) were randomly inspected and eggs within each grid square were counted. The number of parasitoid eggs per 10 grid squares quantified the degree to which a given host species was accepted for oviposition. Acceptability was estimated from the sum of encapsulated and unencapsulated parasitoid eggs.

\section{Host suitability}

Host suitability was assessed for $S$. calamistis, S. poephaga and C. ignefusalis. B. fusca, E. saccharina and $M$. nigrivenella were not included because preliminary observations revealed that larvae exposed to the three Cotesia species did not produce parasitoid cocoons and were thus presumed unsuitable hosts. To assess the degree of host suitability, larvae exposed to parasitoids were placed on diet observed for three possible outcomes: (1) parasitoid cocoons produced, (2) the host pupated or (3) the host died. Parasitoid cocoons were transferred into $20 \mathrm{ml}$ transparent plastic vials and held until adults emerged. For each Cotesia species, the duration of egg-larval, pupal total developmental time was recorded. Dividing the larval and pupal developmental time by the total development time estimated the proportion of larval and pupal period, respectively. Adult parasitoids were counted and sexed. The remaining cocoons in the brood were dissected to identify immature parasitoid mortality. The percentage of host larvae that died after exposure to parasitism by Cotesia species estimated parasitoid-induced host mortality. Intrinsic mortality of unparasitized hosts $(n=30)$ due to natural causes was subtracted from the percentage of hosts that died to prevent inflation of parasitoid host mortality using Abbott's formula (Abbott, 1925). Wiedenmann and Smith (1995) reported that the crambid Diatraea saccharalis (Fabricius) that encapsulated C. flavipes immature life stages remained at a 'terminal larval stage'. In the current study, if the host larval period exceeded three standard deviations from the mean larval period of unparasitized larvae, it was considered to be at terminal larval stage. The percentage of hosts that produced parasitoid cocoons was used to estimate successful parasitization. In the current study, an independent estimate of parasitization and parasitoid-induced host mortality was given. The sum of emergent adults plus adults that did not emerge from cocoons was used to estimate brood size.

\section{Encapsulation}

The presence of partially encapsulated parasitoid eggs (i.e. where parasitoid eggs were surrounded by haemocytes) or the presence of melanized tissue with conspicuous darkish pigmentation served as evidence of encapsulation. Hosts dissected at $24 \mathrm{~h}$ post-parasitism gave an estimate of encapsulation. 
However, the dissections were made only after approximately $9 \%$ of the parasitoid larval development period had passed. By subtracting the percentage of hosts that successfully produced cocoons from the percentage that were accepted provided an overall encapsulation estimate that included a greater proportion of the developmental period. The estimates of host encapsulation were compared.

\section{Suitability ranking}

To determine the most suitable host species for parasitoid development, hosts were ranked by assigning scores for parameter values that differed significantly among hosts. The parameters used for suitability ranking were percentages of hosts parasitized, parasitoid-induced host mortality, and of adult parasitoids emergence, brood size, sex ratio as the percentage of female parasitoids and length of larval period. For percentage of hosts parasitized, brood size, sex ratio and percentage of emerged adults, the largest values were scored ' 3 ', intermediate values were scored ' 2 ' and smallest were scored ' 1 '. For length of larval period and parasitoid-induced host mortality, the smallest values were scored ' 3 ', the intermediate values were scored ' 2 ' and the largest values were scored ' 1 '. A perfect score for all attributes measured would have been 54 . The host species that received the highest accumulative score was considered the most suitable.

\section{Data analysis and reporting}

The independent variables in this experiment were parasitoid and host species. The dependent variables were the percentage of accepted hosts, number of parasitoid egg counts per grid, percentages of hosts that encapsulated parasitoid eggs, percentage of parasitized hosts, hosts that died after an attack by a parasitoid, and of successful emergence of adult parasitoid, sex ratio, parasitoid brood size and parasitoid developmental time. The relationships between the independent and dependent variables were examined using one-way ANOVA (PROC GLM; SAS Institute, 1989). Means were separated using the Tukey test. All percentage data were arcsin transformed before analysis. In the tables, untransformed means $( \pm$ SEM) are presented. The percentage of host species encapsulated (y-axis) was plotted against the different host species ( $x$-axis) using Sigmaplot (1994). The normal distribution of parasitoid brood size was plotted using probabilities that were generated to fit the lognormal distribution (PROC CAPABILITY, SAS Institute, 1989).

\section{Results}

Host acceptability

All borer species were accepted for parasitism by all Cotesia species except for the $M$. nigrivenellaC. chilonis pairing (Table 1). Dissections revealed that all accepted hosts contained parasitoid eggs. The degree to which hosts were accepted for oviposition varied among host species. In general, parasitoids exhibited stronger host acceptance toward hosts that increased reproductive success.

Results from host acceptance studies indicated that $C$. flavipes accepted the greatest percentage of $B$. fusca, $M$. nigrivenella and E. saccharina $(P<0.01$; Table 1). C. sesamiae and C. flavipes accepted a higher percentage of $S$. poephaga than $C$. chilonis $(P<0.0001)$, with no differences in the percentage of $S$. calamistis and C. ignefusalis accepted by the three parasitoid species $(P>0.05)$. Acceptance of a particular host by each of the three parasitoids showed that $S$. calamistis, S. poephaga and C. ignefusalis were readily accepted, B. fusca was less accepted, and E. saccharina and $M$. nigrivenella were the least accepted by the three parasitoids $(P<0.05$, Table 1$)$.

Estimates of clutch size for the same host and different parasitoids followed the general trends as host acceptance (Table 1). Clutch size estimate for C. flavipes was highest in B. fusca, S. calamistis and S. poephaga $(P<0.0001)$. The estimate of clutch size did not differ between $C$. sesamiae and C. flavipes when both species attacked $M$. nigrivenella and E. saccharina $(P>0.05)$. In most acceptable hosts, clutch size was significantly higher for $C$. flavipes than either of the other two Cotesia species. Observation of parasitoid eggs oviposited in larvae of E. saccharina, B. fusca and M. nigrivenella showed no sign of embryonic development.

\section{Host suitability}

\section{Fate of parasitized larvae}

Host larvae that produced parasitoid brood, pupated or died were compared across host and parasitoid (Table 2). Successful parasitization by C. sesamiae was higher on S. calamistis and S. poephaga than on C. ignefusalis. C. flavipes successfully parasitized a significantly higher percentage of $S$. poephaga than either $S$. calamistis or C. ignefusalis, and C. chilonis parasitized a higher percentage of $S$. poephaga and C. ignefusalis than $S$. calamistis larvae (Table 2). A similar trend for successful parasitization of a particular host by each parasitoid was evident when the suitability of hosts across parasitoids was estimated (Table 2). Parasitization of $S$. calamistis was highest by C. sesamiae $(P<0.0001)$. In contrast, parasitization 
Table 1. Comparison of host acceptability and parasitoid clutch size among parasitoid and host species

\begin{tabular}{|c|c|c|c|c|c|c|c|c|}
\hline & $n$ & Cotesia sesamiae $^{1}$ & $n$ & Cotesia flavipes $^{2}$ & $n$ & Cotesia chilonis & $F$ & $P$ \\
\hline \multicolumn{9}{|c|}{ Proportion of hosts accepted } \\
\hline Sesamia calamistis & 6 & $0.90 \mathrm{aA}$ & 6 & $0.83 \mathrm{abA}$ & 6 & $0.73 \mathrm{aA}$ & 3.00 & 0.078 \\
\hline Sesamia poephaga & 6 & $0.98 \mathrm{aA}$ & 6 & $0.97 \mathrm{aA}$ & 6 & $0.73 \mathrm{aB}$ & 5.25 & 0.019 \\
\hline Busseola fusca & 6 & $0.60 \mathrm{bcB}$ & 6 & $0.78 \mathrm{abA}$ & 6 & $0.48 \mathrm{bcB}$ & 7.38 & 0.006 \\
\hline Coniesta ignefusalis & 6 & $0.75 \mathrm{abA}$ & 6 & $0.77 \mathrm{abA}$ & 6 & $0.81 \mathrm{aA}$ & 1.47 & 0.865 \\
\hline Eldana saccharina & 6 & $0.12 \mathrm{~dB}$ & 6 & $0.48 \mathrm{cA}$ & 6 & $0.33 \mathrm{bAB}$ & 6.80 & 0.008 \\
\hline \multirow{3}{*}{ Mussidia nigrivenella } & 6 & $0.34 \mathrm{cdB}$ & 6 & $0.70 \mathrm{bcA}$ & 6 & $0.00 \mathrm{dC}$ & 58.18 & 0.000 \\
\hline & & $F=20.38$ & & $F=8.06$ & & $F=27.9$ & & \\
\hline & & $P=0.0001$ & & $P=0.001$ & & $P=0.0001$ & & \\
\hline \multicolumn{9}{|c|}{ Number of parasitoid eggs/10 grids } \\
\hline S. calamistis & 6 & $0.90 \mathrm{aA}$ & 6 & $0.76 \mathrm{abB}$ & 6 & $0.67 \mathrm{aB}$ & 5.00 & 0.022 \\
\hline S. poephaga & 6 & $0.93 \mathrm{aA}$ & 6 & $0.90 \mathrm{aA}$ & 6 & $0.63 \mathrm{aB}$ & 10.74 & 0.001 \\
\hline B. fusca & 6 & $0.33 \mathrm{bcB}$ & 6 & $0.61 \mathrm{bcA}$ & 6 & $0.37 \mathrm{bcB}$ & 7.11 & 0.007 \\
\hline C. ignefusalis & 6 & $0.43 \mathrm{bB}$ & 6 & $0.50 \mathrm{cAB}$ & 6 & $0.57 \mathrm{abA}$ & 0.66 & 0.532 \\
\hline E. saccharina & 6 & $0.07 \mathrm{~dB}$ & 6 & $0.34 \mathrm{dA}$ & 6 & $0.17 \mathrm{bAB}$ & 5.21 & 0.019 \\
\hline \multirow[t]{3}{*}{ M. nigrivenella } & 6 & $0.05 \mathrm{cdB}$ & 6 & $0.30 \mathrm{cdA}$ & 6 & $0.00 \mathrm{dC}$ & 17.94 & 0.000 \\
\hline & & $F=69.31$ & & $F=17.09$ & & $F=23.06$ & & \\
\hline & & $P=0.0001$ & & $P=0.0001$ & & $P=0.0001$ & & \\
\hline
\end{tabular}

Means within a row and observation followed by different capital letter, and means within a column followed by different lower case letter, are significantly different at $P<0.05$ (Tukey test).

${ }^{1}$ Values presented for host acceptability and parasitoid clutch size are per cohort of 10 fourth-instar host larvae.

${ }^{2}$ Parasitoid eggs within an area of ten microscopic fields of vision under $\times 40$ magnification $(\sim 0.93 \%$ of the total Petri dish surface) is used to generate clutch size estimate.

of C. ignefusalis by $C$. chilonis was significantly higher than by $C$. sesamiae $(P<0.0001)$. No significant differences were found in parasitism of $S$. poephaga among the three Cotesia species $(P>0.05)$.

The percentage of $C$. ignefusalis larvae exposed to $C$. sesamiae, which subsequently pupated, was higher than that of the two Sesamia species (Table 2). Also higher percentages of S. calamistis and C. ignefusalis than of S. poephaga larvae pupated when exposed to C. flavipes. Similarly, the percentage of $S$. calamistis larvae that pupated was higher than that of either C. ignefusalis or $S$. poephaga when exposed to $C$. chilonis.

Table 2. Percentage of hosts that produced parasitoid cocoon, pupated or died

\begin{tabular}{|c|c|c|c|c|c|c|c|c|}
\hline & $n$ & Cotesia sesamiae & $n$ & Cotesia flavipes & $n$ & Cotesia chilonis & $F$ & $P$ \\
\hline \multicolumn{9}{|l|}{ Parasitized } \\
\hline Sesamia calamistis & 6 & $78.1 \pm 4.7 \mathrm{aA}$ & 6 & $52.1 \pm 4.7 \mathrm{bB}$ & 6 & $46.9 \pm 4.5 \mathrm{bB}$ & 9.26 & 0.001 \\
\hline Sesamia poephaga & 6 & $74.7 \pm 4.9 \mathrm{aA}$ & 6 & $73.6 \pm 4.7 \mathrm{aA}$ & 6 & $64.8 \pm 4.5 \mathrm{aA}$ & 2.19 & 0.129 \\
\hline Coniesta ignefusalis & 6 & $\begin{array}{l}46.1 \pm 4.5 \mathrm{bB} \\
F=16.32 \\
P=0.001\end{array}$ & 6 & $\begin{array}{l}54.4 \pm 4.9 \mathrm{bAB} \\
F=7.23 \\
P=0.003\end{array}$ & 6 & $\begin{array}{l}72.2 \pm 3.9 \mathrm{aA} \\
F=8.17 \\
P=0.001\end{array}$ & 11.48 & 0.001 \\
\hline \multicolumn{9}{|l|}{ Pupated } \\
\hline S. calamistis & 6 & $19.4 \pm 4.4 \mathrm{bB}$ & 6 & $38.0 \pm 4.4 \mathrm{aA}$ & 6 & $48.1 \pm 4.2 \mathrm{aA}$ & 7.46 & 0.002 \\
\hline S. poephaga & 6 & $13.0 \pm 4.7 \mathrm{bB}$ & 6 & $12.2 \pm 4.4 \mathrm{bB}$ & 6 & $22.6 \pm 4.2 \mathrm{bA}$ & 2.18 & 0.130 \\
\hline C. ignefusalis & 6 & $\begin{array}{l}41.0 \pm 4.2 \mathrm{aA} \\
F=15.4 \\
P=0.001\end{array}$ & 6 & $\begin{array}{l}37.3 \pm 4.7 \mathrm{aAB} \\
F=12.5 \\
P=0.001\end{array}$ & 6 & $\begin{array}{l}23.7 \pm 3.7 \mathrm{bB} \\
F=9.07 \\
P=0.001\end{array}$ & 7.50 & 0.002 \\
\hline \multicolumn{9}{|l|}{ Died } \\
\hline S. calamistis & 6 & $2.4 \pm 2.1 \mathrm{bB}$ & 6 & $10.0 \pm 2.1 \mathrm{aA}$ & 6 & $5.0 \pm 2.0 \mathrm{bAB}$ & 7.30 & 0.003 \\
\hline S. poephaga & 6 & $12.2 \pm 2.2 \mathrm{aA}$ & 6 & $14.2 \pm 2.1 \mathrm{aA}$ & 6 & $12.6 \pm 2.0 \mathrm{aA}$ & 0.12 & 0.886 \\
\hline C. ignefusalis & 6 & $\begin{array}{l}13.0 \pm 2.0 \mathrm{aA} \\
F=11.4 \\
P=0.001\end{array}$ & 6 & $\begin{array}{l}8.3 \pm 2.2 \mathrm{aAB} \\
F=1.13 \\
P=0.337\end{array}$ & 6 & $\begin{array}{l}4.1 \pm 1.7 \mathrm{bB} \\
F=8.95 \\
P=0.001\end{array}$ & 7.84 & 0.002 \\
\hline
\end{tabular}

Means within a row and observation followed by different capital letter, and means within a column followed by different lower case letter, are significantly different at $P<0.05$ (Tukey test). 
The percentage of $S$. calamistis larvae that pupated differed between $C$. sesamiae and the other two Cotesia species $(P<0.05)$. Also, there were significant differences among parasitoid species in the mean percentage of $S$. poephaga and $C$. ignefusalis larvae that pupated $(P<0.05)$. Host larvae that remained at the terminal larval stage varied for each parasitoid-host pairing. No terminal host larval stages were noted for $S$. calamistis larvae exposed to $C$. sesamiae, while $6 \%$ of the exposed hosts remained terminal when exposed to $C$. flavipes and C. chilonis. Six, 8 and 14\% of S. poephaga larvae exposed for parasitism by C. sesamiae, C. flavipes and $C$. chilonis, respectively, remained in the terminal larval stage. Similarly, 8,4 and $4 \%$ of the C. ignefusalis exposed to parasitism by C. sesamiae, C. flavipes and C. chilonis, respectively, remained in terminal larval stage.

Similarly, hosts that died after being exposed to parasitoids varied significantly among parasitoids $(P<0.05$, Table 2$)$. Host mortality was consistently highest in $S$. poephaga $(P<0.05)$. Hosts exposed for parasitism to $C$. flavipes showed a greater mortality when compared with hosts exposed to the other two Cotesia species $(P<0.05)$. No trends were found when combining the proportion of hosts that pupated with host death from unsuccessful parasitization.
Brood size, sex ratio, adult emergence and developmental time

Few significant differences were found in brood size, sex of brood and percentage of successfully emerged parasitoid adults (Table 3). Brood size and adult emergence of the three Cotesia spp. were consistently smaller when parasitizing C. ignefusalis compared with Sesamia spp. C. chilonis ranked lowest when compared among the three parasitoid species in terms of brood size, adult emergence and sex ratio except for sex ratio in S. calamistis. Brood size per host differed with host species (Fig. 1). C. sesamiae and C. flavipes exhibited a high plasticity in terms of brood size in the different host species. Brood size varied considerably in noctuid hosts (S. calamistis and S. poephaga) and to a much lesser extent in C. ignefusalis. Differences in developmental time among host and parasitoid species were observed (Table 3). For the same parasitoid, development time was longer with $S$. poephaga than S. calamistis or C. ignefusalis as the hosts (Table 3). Differences in the length of the larval period were more apparent. C. chilonis developed faster than the other two Cotesia when $C$. ignefusalis $(P<0.001)$ or S. poephaga was the host $(P<0.001)$. Similarly, $C$. flavipes developed faster than $C$. sesamiae with S. poephaga as the host $(P<0.006)$.

Table 3. Brood size, percentage of successfully emerged adults per total number of cocoons, proportion of female parasitoid progeny and number of days for parasitoid larva to emerge from host

\begin{tabular}{|c|c|c|c|c|c|c|c|c|}
\hline & $n$ & Cotesia sesamiae & $n$ & Cotesia flavipes & $n$ & Cotesia chilonis & $F$ & $P$ \\
\hline \multicolumn{9}{|l|}{ Brood size } \\
\hline Sesamia calamistis & 49 & $90.6 \pm 6.8 \mathrm{aA}$ & 36 & $69.8 \pm 6.4 \mathrm{aB}$ & 33 & $49.4 \pm 6.8 \mathrm{aC}$ & 5.31 & 0.008 \\
\hline Sesamia poephaga & 49 & $67.8 \pm 4.1 \mathrm{aA}$ & 43 & $65.6 \pm 3.9 \mathrm{aA}$ & 37 & $43.6 \pm 4.2 \mathrm{aB}$ & 8.57 & 0.001 \\
\hline Coniesta ignefusalis & 33 & $\begin{array}{c}41.2 \pm 6.8 \mathrm{bA} \\
F=8.76 \\
P=0.001\end{array}$ & 36 & $\begin{array}{c}38.9 \pm 4.6 \mathrm{bA} \\
F=10.92 \\
P=0.001\end{array}$ & 46 & $\begin{array}{c}31.7 \pm 3.4 \mathrm{bA} \\
F=7.76 \\
P=0.001\end{array}$ & 2.70 & 0.070 \\
\hline \multicolumn{9}{|l|}{ Emergent adults } \\
\hline S. calamistis & 49 & $88.2 \pm 4.7 \mathrm{abA}$ & 36 & $92.9 \pm 4.5 \mathrm{aA}$ & 33 & $68.6 \pm 4.7 \mathrm{abB}$ & 14.34 & 0.001 \\
\hline S. poephaga & 49 & $93.6 \pm 2.9 \mathrm{aA}$ & 43 & $88.5 \pm 2.7 \mathrm{aA}$ & 37 & $75.1 \pm 3.1 \mathrm{aB}$ & 20.66 & 0.001 \\
\hline C. ignefusalis & 33 & $\begin{array}{c}77.1 \pm 4.7 \mathrm{bA} \\
F=8.2 \\
P=0.001\end{array}$ & 36 & $\begin{array}{c}69.2 \pm 4.4 \mathrm{bA} \\
F=14.66 \\
P=0.001\end{array}$ & 46 & $\begin{aligned} 62.8 & \pm 2.4 \mathrm{bA} \\
F & =4.02 \\
P & =0.02\end{aligned}$ & 2.34 & 0.057 \\
\hline \multicolumn{9}{|l|}{ Female brood } \\
\hline S. calamistis & 49 & $61.8 \pm 6.8 \mathrm{aA}$ & 36 & $56.3 \pm 6.5 \mathrm{aA}$ & 33 & $56.1 \pm 6.8 \mathrm{aA}$ & 0.31 & 0.738 \\
\hline S. poephaga & 49 & $59.6 \pm 4.2 \mathrm{aA}$ & 43 & $52.5 \pm 4.1 \mathrm{aA}$ & 37 & $31.5 \pm 4.3 \mathrm{bB}$ & 12.01 & 0.001 \\
\hline C. ignefusalis & 33 & $\begin{array}{c}53.9 \pm 6.8 \mathrm{aAB} \\
F=0.39 \\
P=0.677\end{array}$ & 36 & $\begin{array}{c}62.5 \pm 4.6 \mathrm{aA} \\
F=1.34 \\
P=0.265\end{array}$ & 46 & $\begin{array}{c}45.2 \pm 3.5 \mathrm{aB} \\
F=5.34 \\
P=0.006\end{array}$ & 4.08 & 0.019 \\
\hline \multicolumn{9}{|l|}{ Developmental time } \\
\hline S. calamistis & 49 & $11.8 \pm 0.6 \mathrm{bA}$ & 36 & $11.1 \pm 0.5 \mathrm{bA}$ & 33 & $11.2 \pm 0.6 \mathrm{aA}$ & 1.88 & 0.163 \\
\hline S. poephaga & 49 & $15.9 \pm 0.4 \mathrm{aA}$ & 43 & $13.9 \pm 0.3 \mathrm{aB}$ & 37 & $12.5 \pm 0.4 \mathrm{aC}$ & 12.91 & 0.001 \\
\hline C. ignefusalis & 33 & $\begin{array}{c}12.4 \pm 0.6 \mathrm{bA} \\
F=15.29 \\
P=0.001\end{array}$ & 36 & $\begin{array}{c}11.9 \pm 0.6 \mathrm{bA} \\
F=9.80 \\
P=0.001\end{array}$ & 46 & $\begin{array}{c}11.3 \pm 0.6 \mathrm{aA} \\
F=12.47 \\
P=0.001\end{array}$ & 5.00 & 0.010 \\
\hline
\end{tabular}

Means within a row and observation followed by different capital letter, and means within a column followed by different lower case letter, are significantly different at $P<0.05$ (Tukey-Kramer test). 


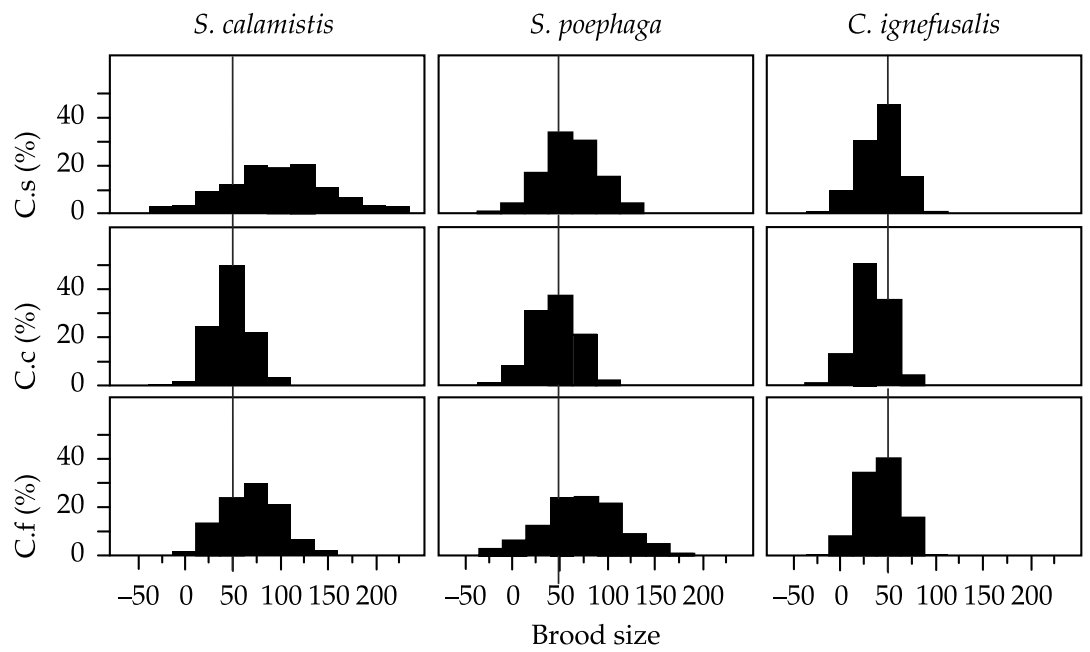

Fig. 1. Distribution of offspring brood by female Cotesia sesamiae (C.s), Cotesia chilonis (C.c) and Cotesia flavipes (C.f) in different host species (PROC CAPABILITY, SAS Institute, 1989). Parasitoid brood distribution across host species was tested under the assumption of equality of variance (HO: variances are equal versus HA: at least two variances are unequal) using Bartlett's test of homogeneity of variances (Sokal and Rohlf, 1995). Cotesia sesamiae $\left(\chi^{2}=21.2, P=0.0001\right)$, C. flavipes $\left(\chi^{2}=25.9, P=0.0001\right)$ and C. chilonis $\left(\chi^{2}=1.46, P=0.45\right)$.

\section{Encapsulation}

Parasitoid survival was quantified by estimating the percentage of the total accepted hosts that produced parasitoid cocoons. The remainder of the hosts that did not produce cocoons estimated percentage of hosts that encapsulated parasitoid life stages (Fig. 2). With B. fusca, E. saccharina and $M$. nigrivenella as the host, $100 \%$ of all parasitoids of all three species were encapsulated. By contrast, encapsulation was only $11.1 \%$ in S. calamistis for C. sesamiae, $27.7 \%$ in $S$. poephaga for C. flavipes and $10.9 \%$ in C. ignefusalis for C. chilonis (Fig. 2A-C).

Dividing the immature parasitoid development in two temporal periods (Fig. 2D-F) compared the rate of encapsulation in the different host species. The first period covered the first $24 \mathrm{~h}$ after host exposure and the second the time from host exposure until parasitoid larvae emergence. Early encapsulation of parasitoid eggs was most prevalent in those hosts that were unsuitable, i.e. B. fusca, E. saccharina and M. nigrivenella. With the exception of the C. sesamiae-S. calamistis pairing, all parasitoid-host pairings showed evidence of encapsulation during the first $24 \mathrm{~h}$ period. The percentage of suitable hosts (S. calamistis, S. poephaga and C. ignefusalis) that encapsulated parasitoid eggs were $<10 \%$ for C. sesamiae, $<20 \%$ for C. flavipes and $<9 \%$ for $C$. chilonis during the first $24 \mathrm{~h}$ period (Fig. 2). By contrast, the percentage of non-suitable hosts (B. fusca, E. saccharina and $M$. nigrivenella) that encapsulated parasitoid eggs were $>40 \%$ for $C$. sesamiae, $>20 \%$ for $C$. flavipes and $>23 \%$ for C. chilonis. With the exception of the
C. sesamiae-S. calamistis pairing $(0 \%)$, all other parasitoid-host pairings showed evidence of encapsulation during the first $24 \mathrm{~h}$ period.

\section{Suitability ranking}

Based on the ranking scores, S. calamistis was the most suitable host with a total score of $50(92.6 \%)$, followed by $S$. poephaga with a total of $42(77.8 \%)$, while C. ignefusalis with a total score of $38(70.4 \%)$ was the least suitable.

\section{Discussion}

As also shown by Ngi-Song et al. (1995), C. sesamiae tended not to accept hosts when oviposition would not lead to a reproductive gain. By contrast, the exotic parasitoids $C$. flavipes and $C$. chilonis readily accepted both suitable and non-suitable hosts. C. chilonis was the only parasitoid that did not accept the cob boring M. nigrivenella. Suitability of indigenous and exotic gramineous borers in East Africa has been evaluated for the three parasitoids in the laboratory. Mohyuddin (1971) showed that C. partellus was the most preferred and E. saccharina the least preferred host for C. sesamiae and C. flavipes. Ngi-Song et al. (1995) and Oketch and Overholt (1996) reported that C. sesamiae, C. flavipes and C. chilonis successfully parasitized larvae of C. partellus, C. orichalcociliellus (Strand) and S. calamistis. In southern Africa, C. sesamiae is reported as an important mortality factor of $B$. fusca in the field (van Rensburg et al., 1988; Kfir and Bell, 
A

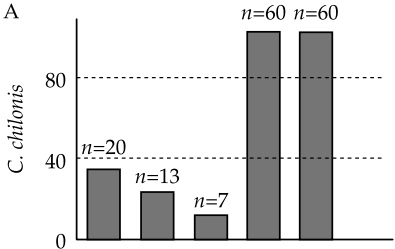

B

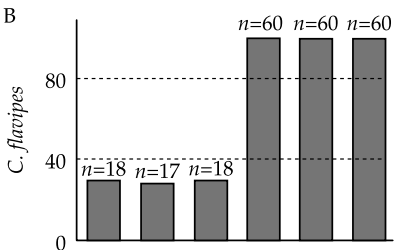

C

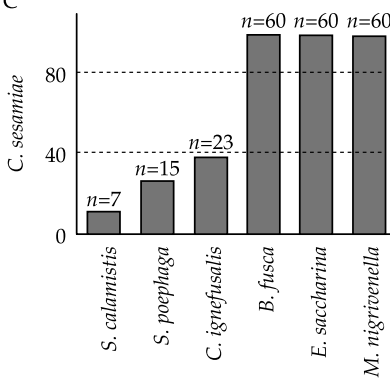

Encapsulation (\% hosts accepted)

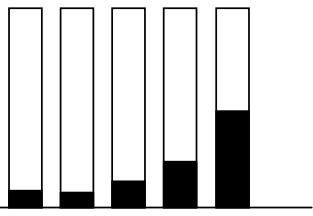

E

F

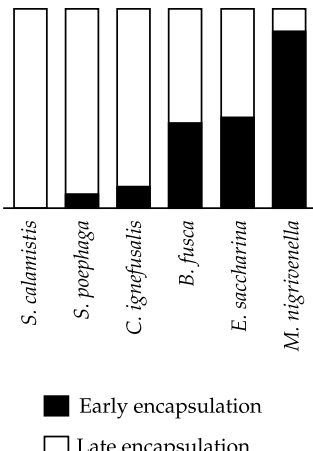

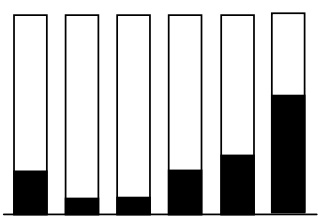

Fig. 2. Comparison of the rate of encapsulation of parasitoid life stages across different hosts. A-C Overall encapsulation rate values were estimated by subtracting the number of successfully parasitized hosts from the number, which were accepted for parasitism by Cotesia species. D-F Comparison between early (shaded) versus late encapsulation (blank) of parasitoid life stages. Parasitized hosts dissected as early as $2 \mathrm{~h}$ post-parasitism gave estimate of early encapsulation of parasitoid eggs and second estimate of late encapsulation that covers the period from $2 \mathrm{~h}$ post-parasitism up to prior to parasitoid larval emergence from the host.

1993). However, the C. sesamiae population in the present study originated from the Kenyan coast, which is encapsulated in B. fusca. Compatible C. sesamiae-B. fusca relationships have been observed in South Africa (Ullyett, 1935; van Rensburg et al., 1988; Kfir and Bell, 1993; Kfir, 1995, 1998), Zimbabwe (Chinwada et al., 2003), inland Kenya (Ngi-Song et al., 1998), Uganda (MatamaKauma et al., 2001), Ethiopia (Getu et al., 2001) and Tanzania (Nsami et al., 2001). Apparently, C. sesamiae and B. fusca are compatible in much of southern and East Africa, but they are rare in western Africa (Schulthess et al., 1997; Ndemah et al., 2007).

Furthermore, for several stemborer species, various populations have been shown to exist in Africa. For example, a phylogenetic analysis by Sezonlin et al. (2006) separated B. fusca populations on maize in Africa into three mitochondrial clades: one from West Africa, and two from East, southern and Central Africa, which includes Cameroon. Likewise, for E. saccharina and S. calamistis, a South African and a West African clade and an Ethiopian clade were identified by Ong'amo et al. (2008) and Assefa et al. (2006), respectively. The stemborer populations vary in host range and climatic requirements, which may also affect the performance of the parasitoid. The present findings suggest, however, that differences in host populations play a minor role in their suitability to the three parasitoids.

A comparison with existing lists of aboriginal and new association host records for C. sesamiae, C. flavipes and C. chilonis (Gifford and Mann, 1967; Yasumatsu, 1967; Kajita and Drake, 1969; Mohyuddin, 1971; Nagaraja, 1971; Brénière and Bordat, 1982; Polaszek and Walker, 1991; Walker, 1994) shows that S. poephaga and C. ignefusalis constitute new host records for $C$. flavipes and C. chilonis, and S. poephaga for C. sesamiae.

The present study indicated differences in the suitability of host species for Cotesia development. C. sesamiae parasitized a greater percentage of $S$. calamistis than either C. flavipes or C. chilonis, but all three Cotesia species parasitized similar percentages of $S$. poephaga. Despite the absence of a co-evolutionary co-adaptive history, C. chilonis attacked a higher percentage of C. ignefusalis than either of the other two Cotesia species. In a laboratory study, Wiedenmann and Smith (1995) found that $C$. chilonis parasitized a higher percentage of the pyralid D. saccharalis (Fabricius), a New World stemborer, than C. flavipes. Neither parasitoid has an old association with the host. Mohyuddin (1971) considered C. flavipes as primarily a parasitoid of Pyralidae (including the stemboring genera Chilo and Diatraea), while C. sesamiae appears to have a wider host range including noctuids (Sesamia and Busseola species) and crambids (Chilo spp.).

In the present study, a large difference in the mortality among $S$. calamistis, $S$. poephaga and C. ignefusalis offered for parasitism to C. sesamiae was found. Ngi-Song et al. (1995) showed a similar trend with native stemborers in East Africa. The reasons for high mortalities observed in S. poephaga exposed to Cotesia species could be due to the relatively high encapsulation rates, which were higher than those of S. calamistis and C. ignefusalis. Moreover, development time was prolonged when S. poephaga was the host compared with S. calamistis or C. ignefusalis, suggesting unfavourable developmental conditions. In addition, the variation in the length of larval development was higher for C. sesamiae and C. flavipes than for C. chilonis. C. chilonis might benefit from having a relatively 
short larval period as a means to escape from being successfully challenged by the host immune defence. Ngi-Song et al. (1995) reported that total development for $C$. sesamiae was longer on C. partellus than on C. orichalcociliellus; by contrast, C. flavipes required a shorter developmental duration on C. partellus than on C. orichalcociliellus.

Cotesia sesamiae and C. flavipes showed high plasticity compared with $C$. chilonis with respect to brood allocation in different host species. All three parasitoid species produced a larger brood size with Sesamia species than with C. ignefusalis as the host. In a preliminary experiment, we compared size differences between fourth instar Coniesta and Sesamia larvae, and found that the latter were heavier than the former. As host size increases, parasitoids are also expected to increase their brood size (Charnov and Skinner, 1985). The plasticity with respect to parasitoid brood allocation for $C$. sesamiae and C. flavipes could therefore be an adaptation to differences in host size. Thus we hypothesize that $C$. sesamiae and $C$. flavipes might have evolved under conditions, in which they interacted with hosts that varied in size. Evidence that might support this argument could be drawn from lists of host species of the three species (Polaszek and Walker, 1991; Walker, 1994). By contrast, the host range of C. chilonis is narrow.

The three Cotesia species exhibited a similar host range in the laboratory, with a few biological differences in host acceptance and host suitability. It was interesting to note that there were no differences in the number of suitable hosts among all parasitoids. All three parasitoids, regardless of their co-evolutionary history, successfully parasitized the noctuids S. calamistis and S. poephaga and the pyralid C. ignefusalis, and failed to parasitize the noctuid B. fusca and the pyralids E. saccharina and $M$. nigrivenella. In the current study, E. saccharina was the least accepted stemborer by $C$. sesamiae in comparison across host and parasitoid species. Thus C. sesamiae with the lowest acceptance of this pyralid should have the highest chance to establish in areas with chronic stemborer problems, where E. saccharina is often the most common borer species (Schulthess et al., 1997). The three parasitoids were released in southern Benin, but only $C$. sesamiae permanently established supporting this assumption.

The contention that novel association biological control agents have a broader host range than old association biological control agents (Howarth, 1991; Lockwood, 1993) was not supported by the current data. Nor can we conclusively support the converse argument, which claims no difference in host range between novel and old association biological control agents (Hokkanen and Pimentel,
1984, 1989; Wiedenmann and Smith, 1997), due to insufficient data. As shown for East and southern Africa and Cameroon in Central Africa, various borer species that do not attack crops exist in the wild habitats (Le Rü et al., 2006; Ndemah et al., 2007). By contrast, little quantitative data exist on the diversity of borers on wild hosts in West Africa. Thus future studies should concentrate on the assessment of the relative importance of alternative borer hosts in wild habitats and their suitability for development of Cotesia spp. in order to establish their role in stabilizing pest-parasitoid relationships in cereal systems in West Africa.

\section{Acknowledgements}

The authors thank the IITA-PHMD staff Adenirin Chabi-Olaye, Balogoun, Alex Ahomadegbe, Seraphine and the late Saka Gounou for advice and tremendous technical support.

\section{References}

Abbott W. S. (1925) A method of computing the effectiveness of an insecticide. Journal of Economic Entomology 18, 265-267.

Assefa Y., Mitchell A. and Conlong D. (2006) Phylography of Eldana saccharina Walker (Lepidoptera: Pyralidae). Annales de la Société Entomologique de France 42, 331-337.

Bolaji O. O. and Bosque-Pérez N. A. (1998) Life history and massrearing of Mussidia nigrivenella Ragonot (Lepidoptera: Pyralidae) on artificial diets. African Entomology 6, 101-110.

Bosque-Pérez N. A. and Dabrowski Z. T. (1989) Mass rearing of the maize stem borers Sesamia calamistis and Eldana saccharina at IITA. Towards Insect Resistant Maize for the Third World. Proceedings of the International Symposium on Methodologies for Developing Host Plant Resistance of Maize Insects, pp. 22-26. CIMMYT, Mexico.

Bosque-Pérez N. A., Ubeku J. A. and Polaszek A. (1995) Survey of parasites of Sesamia calamistis (Lepidoptera: Noctuidae) and Eldana saccharina (Lepidoptera: Pyralidae) in Southwestern Nigeria. Entomophaga 39, 367-376.

Brénière J. and Bordat D. (1982) Interest and difficulties of biological control by introduction of natural enemies, case of the rice borers in Africa. Agronomie Tropicale 37, 203-206.

Charnov E. L. and Skinner S. W. (1985) Complementary approaches to the understanding of parasitoid oviposition decisions. Environmental Entomology 14, 383-391.

Chinwada P., Overholt W. A., Omwega C. O. and Mueke J. M. (2003) Geographic differences in host acceptance and suitability of two Cotesia sesamiae populations in Zimbabwe. Biological Control 28, 354-359. 
Conlong D. E. (2001) Indigenous African parasitoids of Eldana saccharina (Lepidoptera: Pyralidae). Proceedings of the South African Sugar Technologists Association 74, 201-211.

Getu E., Overholt W. A. and Kairu E. (2001) Distribution and species composition of stemborers and their natural enemies in maize and sorghum in Ethiopia. Insect Science and its Application 21, 353-359.

Gifford J. R. and Mann G. M. (1967) Biology, rearing and a trial release of Apanteles flavipes in Florida Everglades to control the sugarcane borers. Journal of Economical Entomology 60, 44-47.

GounouS.,Schulthess F., Shanowoer T., Hammond W. N.O., Braima H., Cudjoe A. R., Adjakloe R., Antiwi K. K. and Olaleye I. (1994) Plant Health Research Monograph No. 4. International Institute of Tropical Agriculture, Ibadan.

Greathead D. (1971) A Review of Biological Control in the Ethiopian Region. Commonwealth Agricultural Bureaux, Slough, UK.

Harris K. M. (1962) Lepidopterous stemborers of cereals in Nigeria. Bulletin of Entomological Research 53, 139-171.

Hokkanen H. M. T. and Pimentel D. (1984) New approach for selecting biological control agents. Canadian Entomologist 116, 1109-1121.

Hokkanen H. M. T. and Pimentel D. (1989) New associations in biological control: theory and practice. Canadian Entomologist 121, 829-840.

Howarth F. G. (1991) Environmental impacts of classical biological control. Annual Review of Entomology 36, 485-509.

Ingram W. R. (1958) The lepidopterous stalk borers associated with graminae in Uganda. Bulletin of Entomological Research 49, 67-83.

Kajita H. and Drake E. F. (1969) Biology of Apanteles chilonis and Apanteles flavipes (Hym: Braconidae) parasites of Chilo suppressalis. Mushi 42, 163-179.

Kfir R. (1995) Parasitoids of the African stemborer Busseola fusca (Lepidoptera: Noctuidae) in South Africa. African Entomology 2, 67-68.

Kfir R. (1998) Maize and grain sorghum: southern Africa. In African Cereal Stemborers. Economic Importance, Taxonomy, Natural Enemies and Control (edited by A. Polaszek), pp. 29-38. The ACP-EU Technical Center for Agricultural and Rural Cooperation (CTA)/CAB International, Wallingford.

Kfir R. and Bell R. A. (1993) Inter-seasonal changes in the populations of the African maize stemborer, Busseola fusca Fuller (Lepidoptera: Noctuidae) and its parasitoids in Natal, South Africa. Journal of African Zoology 107, 543-553.

Le Rü B. P., Ong'amo G. O., Moyal P., Muchugu E., Ngala L., Musyoka B., Abdullah Z., Matama-Kauma T., Lada V. Y., Pallangyo B., Omwega C. O., Schulthess F., Calatayud P. A. and Silvain J. F. (2006) Major ecological characteristics of East African noctuid stemborers. Bulletin of Entomological Research 96, $555-563$.
Lockwood J. A. (1993) Environmental issues involved in biological control of rangeland grasshoppers (Orthoptera: Acrididae) with exotic agents. Environmental Entomology (USA) 22, 503-518.

Matama-Kauma T., Kyamanywa S., Ogwang J. A., Omwega C. O. and Willson H. (2001) Cereal stemborer species complex and establishment of Cotesia flavipes Cameron in eastern Uganda. Insect Science and its Application 21, 317-325.

Mochiah M. B., Ngi-Song A. J., Overholt W. A. and Botchey M. (2001) Host suitability of four cereal stem borers (Lepidoptera: Crambidae, Noctuidae) for different geographic populations of Cotesia sesamiae (Cameron) (Hymenoptera: Braconidae) in Kenya. Biological Control 21, 285-292.

Mohyuddin A. I. (1971) Comparative biology and ecology of Apanteles flavipes Cameron and Apanteles sesamiae Cameron as parasites of gramineous borers. Bulletin of Entomological Research 61, 33-39.

Mohyuddin A. I. (1991) Utilization of natural enemies for the control of insect pests of sugar-cane. Insect Science and its Application 12, 19-26.

Mohyuddin A. I., Inayatullah C. and King E. G. (1981) Host selection and strain occurrence in Apanteles flavipes Cameron (Hymenoptera: Braconidae) and its bearing on biological control by graminaceaous stem borers (Lepidoptera: Pyralidae). Bulletin of Entomological Research 71, 575-581.

Nagaraja H. (1971) Morphological differences between Apanteles chilonis (Munakata) and Apanteles sesamiae Cameron (Hymenoptera: Braconidae). Parasites on gramineous moth borers, Tech. Bull. No. 14. CIBC, pp. 59-61.

Ndemah R., Schulthess F., Le Rü B. and Bame I. (2007) Lepidopteran cereal stemborers and associated natural enemies on maize and wild grass hosts in Cameroon. Journal of Applied Entomology 131, 658-668.

Ndemah R., Schulthess F., Poehling H. M. and Borgemeister C. (2001) Natural enemies of lepidopterous borers on maize and elephant grass in the forest zone of Cameroon with special reference to Busseola fusca (Fuller) (Lepidoptera: Noctuidae). Bulletin of Entomological Research 91, 205-212.

Ngi-Song A. J., Overholt W. A. and Ayertey J. N. (1995) Suitability of African gramineous stemborers for development of Cotesia flavipes and Cotesia sesamiae (Hymenoptera: Braconidae). Environmental Entomology 24, 978-984.

Ngi-Song A. J., Overholt W. A. and Stouthamer R. (1998) Suitability of Busseola fusca and Sesamia calamistis (Lepidoptera: Noctuidae) for the development of two populations of Cotesia sesamiae (Hymenoptera: Braconidae) in Kenya. Biological Control 12, 208-214.

Nsami E., Pallangyo B., Mgoo V. H. and Omwega C. O. (2001) Distribution and species composition of cereal stemborers in the eastern zone of Tanzania. Insect Science and its Application 21, 347-351.

Oketch S. H. O. and Overholt W. A. (1996) Comparative biology of Cotesia chilonis (Hymenoptera: Braconidae) 
on selected African gramineous stemborers. Biocontrol Science and Technology 6, 595-602.

Ong'amo G. O., Le Rü B. P., Moyal P., Calatayud P. A., Le Gall P., Ogol C. K. P. O., Kokwaro E. D., CapdevielleDulac C. and Silvain J. F. (2008) Host-plant diversity of Sesamia calamistis Hampson (Lepidoptera: Noctuidae): Cytochrome $b$ gene sequences reveal local genetic differentiation. Entomologia Experimentalis et Applicata $128,154-161$.

Overholt W. A., Ochieng J. O., Lammers P. and Ogedah K. (1994) Rearing and field release methods for Cotesia flavipes Cameron (Hymenoptera: Braconidae), a parasitoid of tropical gramineous stemborers. Insect Science and its Application 15, 253-259.

Polaszek A. K. and Walker A. K. (1991) The Cotesia flavipes species complex parasitoids of cereal stem borers in the tropics. Redia 74, 335-341.

SAS Institute (1989) User's Guide: Statistics. SAS Institute, Cary, NC.

Schulthess F., Bosque-Perez N. A., Chabi-Olaye A., Gounou S., Ndemah R. and Goergen G. (1997) Exchange of natural enemies of lepidopteran cereal stemborers between African regions. Insect Science and its Application 17, 97-108.

Sétamou M., Schulthess F., Poehling H.-M. and Borgemeister C. (2000) Host plants and population dynamics of the cob borer Mussidia nigrivenella Ragonot (Lepidoptera: Pyralidae) in Benin. Environmental Entomology 29, 516-524.

Sezonlin M., Dupas S., Le Rü B., Le Gall P., Moyal P., Calatayud P. A., Giffard I. and Silvain J. F. (2006) Phylogeography and population genetics of the maize stalk borer Busseola fusca (Lepidoptera, Noctuidae) in sub-Saharan Africa. Molecular Ecology 15, 407-420.
Sigmaplot $^{\circledR}$ (1994) Sigmaplot. In Scientific Graphing Software. Jandel Corporation, Version 2.0.

Smith J. W. Jr, Wiedenmann R. N. and Overholt W. A. (1993) Parasites of Lepidopteran Stemborers of Tropical Gramineous Plants. ICIPE Science Press, Nairobi. 89 pp.

Sokal R. R. and Rohlf F. J. (1995) Biometry. The Principles and Practices of Statistics in Biological Research, 3rd edn. Freeman, San Francisco, CA.

Ullyett G. C. (1935) Notes on Apanteles sesamiae Cameron, a parasite of the maize stalk borer (Busseola fusca Fuller) in South Africa. Bulletin of Entomological Research 26, 253-262.

van Rensburg J. B., Giliomee J. H. and Walters M. C. (1988) Aspects of the injuriousness of the maize stalk borer Busseola fusca larvae on the growth and yield of maize. Bulletin of Entomological Research 78, $101-110$.

Walker A. K. (1994) Microgastrine (Hymenoptera: Braconidae) parasitizing cereal stemborers in Africa. Bulletin of Entomological Research 84, 421-434.

Wiedenmann R. N. and Smith J. W. Jr (1995) Parasitization of Diatraea saccharalis (Lepidoptera: Pyralidae) by Cotesia chilonis and C. flavipes (Hymenoptera: Braconidae). Environmental Entomology 24, 950-961.

Wiedenmann R. N. and Smith J. W. Jr (1997) Novel associations and importation biological control: the need for ecological and physiological equivalencies. Insect Science and its Application 17, 51-60.

Yasumatsu K. (1967) Distribution and bionomics of natural enemies of rice stem borers: research on the natural enemies of rice stem borers. Mushi 39, 33-44.

Zhou G., Overholt W. A. and Kimani-Njogu S. W. (2003) Species richness and parasitism in an assemblage of parasitoids attacking maize stem borers in coastal Kenya. Ecological Entomology 28, 109-118. 